\title{
Cryopreservation of ram epididymis spermatozoa post-slaughter - A feasible biotechnique?
}

\author{
Sildivane Silva ${ }^{*}$, Felipe Almeida ${ }^{2}$ Ellen Silva ${ }^{2}$, Helder Souza ${ }^{2}$, Thalles Moura ${ }^{2}$, Joane Vieira ${ }^{2}$, Andreia Souza ${ }^{3}$, \\ Maria Madalena Guerra ${ }^{2}$ \\ From 5th Congress of the Brazilian Biotechnology Society (SBBIOTEC) \\ Florianópolis, Brazil. 10-14 November 2013
}

\section{Background}

Gametes for breeding high-value livestock is commonly preserved in gene banks for later use in assisted reproduction programs. Such material can be used in artificial insemination or embryos transfer in the field as well as embryos in vitro production [1]. However, when these animals die, genetic material may be lost if it is not possible to recover and preserve spermatozoa from epididymis. Thus, our aim is to establish a recovery technique of ram sperm epididymal post-slaughter and to test its postcryopreservation viability.

\section{Methods}

Ten rams were slaughtered and testis-epididymis of each animal was placed in individual bags and sent to the Andrology Laboratory (UFRPE). Epididymis were separated, cleaned (alcohol 70\%) underwent a slicing technique and immersed in $5.0 \mathrm{~mL}$ of Tris buffer $(375 \mathrm{mM}$ Tris, $124 \mathrm{mM}$ citric acid, $41.6 \mathrm{mM}$ fructose, $\mathrm{pH} 7.0$ ) for sperm migration for 10 minutes [2]. The suspension bufferspermatozoa from each animal was evaluated for motility $(0-100 \%)$ and vigor $(0-5)$ and when approved $(60 \% / 2)$, diluted in Tris-yolk (20\% egg-yolk, $5 \%$ glycerol, pH 7.4), packed in straws $(0.25 \mathrm{~mL})$, cryopreserved in an automated system $\left(\mathrm{TK} 3000^{\circledR}\right)$ and stored $\left(-196^{\circ} \mathrm{C}\right)$. After thawing $\left(37^{\circ} \mathrm{C} / 30 \mathrm{~s}\right)$, semen samples were evaluated for kinematic $\left(\mathrm{SCA}^{\circledR}\right)$ and structural integrity (plasma membrane-PI/CDF; mitochondrial membrane potentialJC1; acrosome-FITC/PNA).

\section{Results and conclusions}

Data were expressed as mean \pm sd. From 10 samples, $70 \%$ were initially approved for cryopreservation. After

${ }^{1}$ Centro de Biotecnologia (CBiotec) da Universidade Federal da Paraíba,

Campus I, João Pessoa, PB, Brazil

Full list of author information is available at the end of the article thawing, the following values were obtained: total motility $(64.73 \pm 7.10)$, progressive motility $(19.97 \pm 4.26)$, plasma membrane integrity $(39.39 \pm 4.71)$, mitochondrial membrane potential $(88.81 \pm 3.44)$ and acrosome integrity $(49.16 \pm 0.76)$. These results are consistent with other results of post-thaw ram semen obtained by ejaculation $[3,4]$ as well as are indicative of function and structure preservation of sperm cell [5]. Thus, we concluded that cryopreservation of ram epididymal spermatozoa is a feasible biotechnique for germplasm conservation of animals after slaughter.

\section{Acknowledgements}

The authors are grateful to the FACEPE, CAPES, RENORBIO and CNPq.

\section{Authors' details}

${ }^{1}$ Centro de Biotecnologia (CBiotec) da Universidade Federal da Paraíba, Campus I, João Pessoa, PB, Brazil. ²Laboratório de Andrologia (ANDROLAB) da Universidade Federal Rural de Pernambuco, Campus I, Recife, PE, Brazil. ${ }^{3}$ Departamento de Zootecnia da Universidade Federal Rural de Pernambuco, Campus I, João Pessoa, PB, Brazil.

Published: 1 October 2014

References

1. Foote $\mathrm{RH}$ : The history of animal insemination: selected notes and notables. Anim Sci 2002, 80:1-10, J.

2. Almeida FC, Gomes WA, Souza HM, Batista AM, Silva SV, Guerra MMP: Effect of stabilization time on cryopreservation of spermatozoa obtained from bull epididymis. International Symposium on Animal Biology of Reproduction 2012, 4:123.

3. Silva EC, Cajueiro JF, Silva SV, Soares PC, Guerra MM: Effect of antioxidants resveratrol and quercetin on in vitro evaluation of frozen ram sperm. Theriogenology 2012, 77(8):1722-1726.

4. Maia Mde S, Bicudo SD, Sicherle CC, Rodello L, Gallego IC: Lipid peroxidation and generation of hydrogen peroxide in frozen-thawed ram semen cryopreserved in extenders with antioxidants. Anim Reprod Sci 2010, 122(1-2):118-123.

5. Barbas JP, Mascarenhas RD: Cryopreservation of domestic animal sperm cells. Cell Tissue Bank 2009, 10(1):49-62. 
doi:10.1186/1753-6561-8-S4-P166

Cite this article as: Silva et al:: Cryopreservation of ram epididymis

spermatozoa post-slaughter - A feasible biotechnique? BMC Proceedings

2014 8(Suppl 4):P166.

Submit your next manuscript to BioMed Central and take full advantage of:

- Convenient online submission

- Thorough peer review

- No space constraints or color figure charges

- Immediate publication on acceptance

- Inclusion in PubMed, CAS, Scopus and Google Scholar

- Research which is freely available for redistribution

Submit your manuscript at 